\title{
The business of dental practice
}

\author{
Niken Widyanti Sriyono \\ Department of Community and Preventive Dentistry \\ Faculty of Dentistry Gadjah Mada University \\ Yogyakarta - Indonesia
}

\begin{abstract}
Globalization including General Agreement on Trade in Services (GATS) and Asia Fair Trade Agreement (AFTA) are a new free trade system. In globalization era, there will be an intense and free competition in looking for jobs throughout the world. This new system will affect the health services system in which health services tend to follow an industrial model. Meaning that dentistry or dental health services tend to be part of a business system, and this system has caused controversy among the community and the profession itself. The results of the discussion revealed that professional and business of dentistry is compatible and complementary. The tendency of increasing number of legal form of practice (group and a professional corporation) and the worldwide advertisement of these practices supported the premise that delivering dental practice tends to follow the industrial model. Dentists should not only more focus on achieving financial success in running the business of practice but profession should have the most concern for the people who seek their services. Delivering quality of dental care depends on the high skill of the dentist and on the satisfactory income for the survival of the practice in the long run, and this make the practice will be viewed by the public and profession as being appropriate and of high quality. Facing the globalization, besides possessing high clinical skill, dentists must have a firm understanding of management concepts and apply them in their practice. In conclusion: The profession and the business of dentistry are compatible and complementary. The delivery of the dental services tends to follow the industrial model, which is a current reality. Dentist should concern more on the delivering high quality of dental services, not only focus on the business of the practice, although the satisfactory income is important for the survival growth of the practice in the long run. It is suggested for dentists to follow as much business training or dental practice management training as the dentist can. It is also suggested to give the undergraduate students the basic concepts of dental practice management by putting this in the curriculum.
\end{abstract}

Key words: business, dental practice

Correspondence: Niken Widyanti Sriyono, c/o: Bagian Ilmu Kesehatan Gigi Masyarakat, Fakultas Kedokteran Gigi Universitas Gadjah Mada. Jln. Denta No. II, Sekip Utara Yogyakarta 55281, Indonesia. E-mail: bu_nikensri@ yahoo.com. Telp. (0274) 515307.

\section{INTRODUCTION}

Globalization including General Agreement on Trade in Services (GATS) and Asia Fair Trade Agreement (AFTA) will be implemented soon. Globalization and AFTA are a new free trade system, and this system will have great impact on health services, ${ }^{1}$ specifically dental health service systems. People can work in whatever country they choose, since theoretically there are no borderlines among countries in the world. Therefore, there will be an intense and free competition in looking for jobs throughout the world. Skilled and professional people will have the greatest advantage in competing for these jobs. Consequently, health workers should prepare themselves for globalization and AFTA. Moreover, this new order will also affect the health services system in which health services tend to follow an industrial model. ${ }^{1,2}$ Meaning that dentistry or dental health services tend to be part of a business system, and this system has caused controversy among the community and the profession itself. ${ }^{2}$

As is mentioned above, dentists will face the tough/ intense competition in finding a job. Taking this into consideration therefore, dentists should aware of and know about the dental health status of the community, the projected growth of the dental health manpower, and the demand of the people in buying or using a dental service. ${ }^{3}$ For example, by evaluating the condition of the dental health status of Indonesians and the current dental manpower; in which the dental health status of Indonesian increases for the last 15 years, while the ratio between dentists and population is about $1: 13.000 .{ }^{4}$ Added by the big population of Indonesia (220 million), it means that Indonesia will be considered as a big "market" for dental health personnel not only for the Indonesian but also for regional or may be international dental personnel. As the consequences therefore, there will be more tough/intense competition in carrying out dental health services in Indonesia. Indonesian dentists should aware and prepare themselves in facing globalization and the current reality of the business system in delivering dental services.

Although the big majority of dental practice is still dominated by solo practice but from the field observation showed that there is a tendency that dental practices are growing to be a group of practice/partnership or 
a professional corporation especially in some big cities in Indonesia. Partnership/group practice and a professional corporation is the legal form of business organization, and these practices tend to be managed using a business system.

Therefore, this paper will discuss about the professional and the business of dentistry, will introduce the legal forms of dental practice with their advantages and disadvantages as the current reality of the business system in delivering dental services.

\section{Profession}

Wikipedia, ${ }^{5}$ the free encyclopedia defines that a profession is an occupation that requires extensive training and the study and mastery of specialized knowledge, and usually has a professional association, ethical code and process of certification or licensing. For examples are law, medicine, finance, the military, nursing, the clergy and engineering. A member of a profession is termed professional. A profession is always held by a person, and it is generally that person's way of generating income. Membership in the profession is usually restricted and regulated by a professional association. 5,6

In modern usage, professions tend to have certain qualities in common. However, there is no standard definition of a modern professional. Beyond the classical examples (lawyers, doctors, etc.) there are many groups that claim status as a profession, and many who dispute the status. For example, schoolteachers often refer to their occupation as a profession; even though it is not exclusive, nor is entrance competitive, nor are they self-regulating. 5,7

Contemporary professions arose during the Middle Ages and are represented by fields such as the military, medicine and law. All these held a specific code of ethics, and members were almost universally required to swear some form of oath to uphold those ethics. Each profession also provided and required extensive training in the meaning, value and importance of that oath in the practice of profession. ${ }^{6}$

Freidson ${ }^{8}$ suggests that there are six characteristics that can be used to determine whether a group qualifies as a true profession: 1) members of a profession posses abstract knowledge in their area of expertise, 2) entry into a profession requires prolonged specialized training, 3) a profession regulates itself through licensure and through determining its own standards of education, 4) members of a profession are relatively free of lay control, 5 ) the services provided by a profession are necessary for the ongoing functioning of society and 6) members of a profession has a service orientation rather than a profit orientation

In line with Freidson's qualification of a profession, Jong ${ }^{6}$ stated that all professionals have 4 common requirements: 1) a distinct body of knowledge generally requiring education beyond the usual level, 2) a component of service to society, 3) the right and responsibility to be self-governing, and 4) a code of ethics. Professions, such as dentistry, determine their own standards for licensure and control the numbers of entering professionals, the length and conditions of education, the distribution of services, and to great extend the cost of services. It is society's belief that professionals place the welfare of the patient above their own welfare, which helps support the independence of the professions in regulated society. ${ }^{6,7}$

\section{Characteristic of business}

A business can be defined as any individual or group effort to produce and distribute goods or services for a profit. ${ }^{9}$ In most of the economic systems, four groups play important roles in a business: 1) owners, 2) managers, 3) producers, and 4) consumers. Sometimes, individuals could belong to more than one group. For example, an owner may also be a manager and a producer, and a producer could also be a consumer. Owners are those who use their own capital or obtain capital to begin a business. A business can be owned by a single individual in the form of a sole proprietorship or by a group of individuals in the form of partnership or corporation. Managers are those who have the responsibility for conducting and supervising the operation of a business. Producers perform the actual physical and mental labor necessary to produce the goods or services. Consumers are the buyers of the goods and services produced by the business. ${ }^{10}$

Domer et al. ${ }^{10}$ stated that there are five criteria that can be used to determine if someone is engaged in business: 1) the capital obtained, 2) the goods or service are produced and distributed to consumers, 3) willingness of the consumers to buy the goods or services, 4 ) the production, distribution and sale of goods or services results in profit and 5) the owner of a business is confronted with risks.

\section{Legal forms of practice}

In the management literature, the legal form of practice is the synonymous of the form of business organizations. There are three types of legal forms of practice: 1) sole proprietorship, 2) partnership and 3) professional corporation

Young ${ }^{11}$ divided the mode of practices into 3 basic types: 1) independent solo practice (including associateships), 2) solo with facilities sharing, and 3) partnership-group of practice. But, Domer et al. ${ }^{10}$ divided the mode of practices into 2 basic types: alone (including solo practice and expense sharing), and with others (including one other, general group and multispecialty group).

The legal forms of practice are separate and distinct from the modes of practice. For example, the legal form of solo practice could be a sole proprietorship or cooperation with 2 dentists as stockholders even though one is not actively practicing dentistry. And the legal form of the group practice could be a partnership or corporation. ${ }^{10}$ The majority of dentists seem to practice alone (solo practice), and the predominant legal forms of their practice are the sole proprietorship. ${ }^{7,11}$ 


\section{Partnership}

In general, a partnership is 2 or more dentists agree to share the profit and loss of an enterprise in an unincorporated business. They pool their capital and labors, they share their patients, and they split the practice income and expenses according to a predetermined agreement. ${ }^{10,11}$ Young ${ }^{11}$ stated that this type of legal practice is the most radical departures from the traditional practice. There have been a variety of definitions of this type of practice, but Sarner cit. Young ${ }^{11}$ has pointed out that the crucial characteristic of this method of organization is that the participants share income, facilities and expenses.

Some of the advantages of this partnership are the increase of the capital in beginning of the practice and the control is shared with the partner. Moreover, the division of income often results in higher income than an individual proprietorship because of less downtime of the practice. One of the disadvantages is that the actions of one partner can influence on all other partners. For example, in a malpractice claims against one partner, the other partners could also be influenced by the public opinion and also could be held liability. ${ }^{10,11}$

\section{Corporation or a professional corporation}

This is a true business in which members of the corporation are members by virtue of their purchase of stocks. In this type of legal practice, members are usually opened for dentists, but sometimes it is also opened for someone who wants to invest his money on stocks. A professional corporation is a means to give a legal form of business to the controller of the business, which is separated from the owner with the controller of the business. Therefore the difference between corporate and partnership is in the controller of the business. ${ }^{10}$

As was the partnership, a professional corporation has some advantages, for example: more capital available, the death or withdrawal of one of the members does not affect the life of the organization. While of the disadvantages of a corporate is that one must divide the profits of a corporation with the other stockholders. ${ }^{10}$

\section{DISCUSSION}

As was mentioned above, dentistry or dental service delivery is becoming a business system or industrial model. This makes controversial opinions among dental profession and community, but the professional and business aspects of dentistry are a current reality of dental practice. ${ }^{2}$ Regarding these various opinions, Domer ${ }^{10}$ proposed four premises that can be used as the basic knowledge to discuss the professional and business aspects of dentistry in which health services tend to follow an industrial model. Premise I: Dentistry is a Profession, Premise II: Dentistry is a business, Premise III: Professional and business aspects of dentistry are compatible and complementary, and Premise IV: Management is important to both professional and business aspects of dentistry.
The first premise is that Dentistry is a Profession. Referring to the $1^{\text {st }}$ and $2^{\text {nd }}$ professional characteristic of Freidson ${ }^{8}$ mentioned above, any dentist as a profession should fulfill the $1^{\text {st }}$ and $2^{\text {nd }}$ qualifications of Freidson's. In this regard, the length of dental school curriculum and their focus on both scientific knowledge and skills indicate that dentistry fulfills the first two criteria of a true profession of Freidson's qualifications and also the Wikipedia's definition of a profession as mentioned above.

The existing mechanism for licensure and for the accreditation of dental schools reflects that dentistry should regulate itself and be free of lay control. ${ }^{6}$ Woodall, ${ }^{12}$ Freidson ${ }^{8}$ and Jong ${ }^{6}$ stated that the criterion of autonomy differentiates a profession from a non-profession. Professionals have the special privilege of freedom from the control of outside. However, the autonomy that is granted to the professions is a question that is continually raised by the consumers, the government and the third party such as insurance companies..$^{5}$ The degree of self-regulation in the licensure of individual dentists and in the accreditation of dental schools reveals that dentistry also satisfies the $3^{\text {rd }}$ and $4^{\text {th }}$ criteria of a true profession of Freidson's qualifications and Wikipedia's definition of a profession.

The services provided by individual should be professional reflects that services provided must be necessary to society. Maintaining and improving oral health is critical to the maintenance and improvement of overall health and the quality of life. ${ }^{3,13}$ Therefore, dentistry also satisfies the $5^{\text {th }}$ criterion of a true profession of Freidson's qualifications and Wikipedia's definition of a profession.

Some people interpreted the $6^{\text {th }}$ criterion literally that a professional should be wholly unconcerned with the business aspects and the financial rewards of providing services. The service criterion should not be interpreted literally. ${ }^{7}$ However, if dentists are unconcerned with the business aspects of dentistry they will be unable to provide necessary dental services to the public at a reasonable and affordable cost. ${ }^{7,14}$ The service orientation should be interpreted as meaning that individuals in profession have the most concern for the people who seek their services. ${ }^{12}$ From the discussion above it can be concluded therefore that dentistry is a profession, because it has been proved that dentistry fulfill all criteria of a profession.

The $2^{\text {nd }}$ premise proposed by Domer ${ }^{10}$ is that Dentistry is a business. The first criterion of business is the capitals obtain. Any dental practice needs capital to purchase equipment and supplies, lease or buy an office, and to cover overhead costs for the first several months of its initial operation. Although some dentists work for a salary and do not invest capital in the practice that employs them, the employers should invest capital at when the practice was first established. ${ }^{7}$ Therefore, all dental practice fulfills this first criterion of business.

The $2^{\text {nd }}$ criterion of a business is that services are produced and distributed to consumers. It can happen that individuals could belong to more than one group. An owner 
may also be a manager and a producer, and a producer could also be a consumer. ${ }^{10}$ Usually dentists are being the owner of the dental practice, and also they are in most being the manager and producers in the business of the dental practice. It was supported by Young ${ }^{11}$ that most dental students chose dentistry because they want to "be one's owns boss" (owner and manager) and to work with their hands (producers). ${ }^{15}$ Therefore, dentists and their staffs therefore fulfill the $2^{\text {nd }}$ criterion of a business

Willingness of consumers to buy the services or willingness of consumers to exchange money for goods or services is the $3^{\text {rd }}$ criterion of a business. Money is exchanged for the dental care received either directly from patients (out of pocket) or through the third party. ${ }^{14,16}$ It is clearly therefore, that dentistry fulfills the $3^{\text {rd }}$ criterion of a business.

The $4^{\text {th }}$ criterion of a business is that the production, distribution and sales of goods or services result in a profit. Profit is defined as the excess of revenue over the costs of operating a business. ${ }^{10,16}$ Although most dentists use the term net income rather than profit, for all practical purposes they do make a profit. The operation of most of dental practices does in fact result in a profit or net income for the dentists. ${ }^{10}$ Dentists who invest in and operate a private practice certainly assume the risk of associated with the less of successful of the practice or it may completely fail or they face the risk of a business. Or in other words, dentists should aware of the risk of a dental practice.6,10 The dental practice therefore fulfills the $5^{\text {th }}$ criterion of a business that the owners of a business are confronted with financial risks.

In addition to the five criterion of business mentioned above, Silker ${ }^{14}$ makes a clear statement that private practice dentistry is a business just as banking or McDonald's or the grocery store. A dentist must efficiently run the practice as a business. However, Silker ${ }^{14}$ warned that the more focus on achieving financial success (net income or profit); the more financial success evades the dentists. Possibly the patients can feel when a dentist is sincerely and totally interested in what is best for them. If the dentist is more concerned with the business of dentistry than with the patient's well being, the successful business of dental practice will fail. Moreover, Silker ${ }^{14}$ said that having a dental practice or starting a dental practice, a dentist should get as much business training and marketing courses as soon as the dentist can. From the presentation above it can be concluded that a dental practice is a profession and also a business.

The professional and business aspects of dentistry are compatible and complementary is the $3^{\text {rd }}$ premise of Freidson's. ${ }^{8}$ Domer et al. ${ }^{10}$ compared the professional and business objectives of a dental practice. Examination the professional objectives of a dentist and the commonly accepted objectives of a business showed that they are quite similar. Professional and business objectives both include the following: 1) delivery of services that are needed and valued by the public, 2) continued survival and growth, 3 ) improvement of services through experimentation, the acquisition of new knowledge, and the development of a new process, 4 ) provision of a means for individuals and groups (customers, employers, suppliers, etc.) to satisfy their needs, 5) the provision of an economic service that results in equitable profit or income.

If a dentist were to assume that the professional and business objectives of a practice were not identical, it would be impossible to achieve the objective of professional satisfactorily without achieving the objectives of business as well. For example, delivering high quality of dental care not only depends on the high skill of the dentist, but also depends on a cash flow and sufficient income to buy equipment and other supplies. On the other hand, it would be impossible to get satisfactory income in the long run if the public and profession didn't not viewed the practice as being appropriate and of high quality. ${ }^{10,14}$ Therefore, it is clear that the $3^{\text {rd }}$ premise is fulfilled.

However, many dentists feel uneasy to accept dentistry as both a profession and a business. Traditionally, most dentists have not had sufficient training in running a business for a dental practice; they usually learn from their seniors how to run a practice. They usually prefer clinical aspects of dental works. Young ${ }^{11}$ and Domer et al. ${ }^{10}$ stated that many dentists and dental school do not value that dentistry as profession and as business is compatible. This value resulting in the dental curriculum of some dental schools, in which traditionally the dental curriculums have not included business management.

Premise IV is that Management is important to both the professional and business aspects of dentistry. To operate a dental practice requires many resources, such as personnel, dental supplies, money, etc. Obtaining and utilizing resources to achieve objectives is the universal goals of management. ${ }^{16}$ The experts of dental practice management stated that poor management might cause the practice objectives are not achieved well. Possession of clinical knowledge and skills on the part of dentist and staff is not sufficient for the practice to achieve success. To create a successful practice, besides possessing highly clinical skill, a dentist must have a firm understanding of management concepts and apply them in their practice. ${ }^{10,14}$

Indeed, the dental practice management can be learned through experiences in running or working in a private practice, however this approach is time consuming. Sometimes it results in making unnecessary and costly mistakes. It is suggested therefore, to follow continuing education on dental practice management or spend some amount of money for consulting services relating to practice management. ${ }^{14}$ Therefore, it can be concluded from the discussion above that management is important to the both professional and business aspect of dentistry.

The business aspects of dentistry are a current reality. ${ }^{1,2}$ Actually, Young ${ }^{7}$ has identified the trend of the business of dentistry two decades ago. Young ${ }^{7}$ stated that there have been an increasing number of the legal practice (group practice and a professional corporation) in last decade, or the number of "department store" or "shopping mall" of 
dental practices, which are often franchised or operated on a contract with a parent company doing business in one or more states in America. Meaning that the dental practice is managed using a business system.

It was mentioned above that the professional corporation is a true business. The development of the professional corporation of the dental practice can be identified by the great number of a professional corporation that is advertised worldwide through internet. For example the Medical Tourism: Globalization. ${ }^{17}$ advertised that the group of medical and dental practices in some Thailand's International Hospitals provides complete services for international patient clients with 26 languages. It is also interesting to note, that the advertisement also provides information that the services have $20 \%$ lower cost for some medical and dental care compare with the service cost in USA. The underlying of this advertisement is that the medical and dental services have a similarity in selling the services just like a department store or a shopping mall in giving the price discount in selling their products.

Regarding the trend of the development of a corporate practice, Molin and Molin ${ }^{18}$ stated that dentist must know about the secret agenda of the managed care industry, insurance companies and corporate dental conglomerates in future. Steele ${ }^{19}$ mentioned that dentists are currently in an unprecedented age of prosperity in the dental industry, many practices are enjoying heightened profit. However, Steele ${ }^{19}$ said that prosperity can be dangerous, if it leads to complacency, because dentists should always concern with the patient's well being not only concern with the business of dentistry ${ }^{14}$.

Regarding the discussion above and the current reality that the delivery of dental practice to follow a business system, it is suggested therefore to give the undergraduate students the basic concepts of dental practice management by putting this in the curriculum. It is also important to stress dental students and dentists to understand the basic criteria that enable dentistry to be considered a profession and continually to fulfill that criteria mentioned above. Dentistry have to continue the service orientation and to continue developing appropriate regulatory mechanisms, otherwise, outsider groups will increase their effort to modify the dental care delivery systems. As a result of this, dentistry as profession might possibly be destroyed. ${ }^{10,12}$ In addition to these, although the jobs for dentists in Indonesia are still promising, dentists and also the students of dentistry should aware and prepare them in facing these globalization and AFTA.

It can be concluded that the profession and the business of dentistry are compatible and complementary. The delivery of the dental services tends to follow the industrial model, which is a current reality. Dentist should concern more on the delivering high quality of dental services, not only focus on the business of the practice, although the satisfactory income is important for the survival growth of the practice in the long run. Facing the globalization, besides possessing high clinical skill, dentists must have a firm understanding of management concepts and apply them in their practice.

It is suggested for dentists to follow as much business training or dental practice management training as the dentist can. It is also suggested to give the undergraduate students the basic concepts of dental practice management by putting this in the curriculum. Dental students and dentists should always realize the importance of continually to fulfill the basic criteria of a profession that enable dentistry always to be considered as a profession, otherwise outsider groups will increase their effort to modify the dental care delivery systems. As a result of this, dentistry as profession might possibly be destroyed.

\section{REFERENCES}

1. WHO. General agreement on trade in services (GATS). Available at: www.who.int.entity/trade/glosary/story033/en/index.html. Accessed April 24, 2006.

2. Hamid A. Implications of globalization and multilateral on healthcare services. Berita Akademi 2001; 10(4):1-4.

3. WHO. Oral health for the $21^{\text {st }}$ century, WHO/ORH/Oral 21.94.1. Dist. GENERAL English only, Geneva. 1994. p. 11-12.

4. Sriyono NW. Dental practice management, establishing a dental practice. Kumpulan Makalah Ceramah Ilmiah dan Poster Ilmiah, Peringatan $6^{\text {th }}$ Pendidikan Dokter Gigi Universitas Jember; 2001. h. 320-9.

5. Wikipedia. Profession. Available at: http://en.wikipedia.org/wiki/ profession. Accessed April 4, 2006.

6. Jong AW. Community dental health. $3^{\text {rd }}$ ed. St Louis: Mosby-Year Book, Inc; 1993. p. 299, 305, 307.

7. Young WO. The social setting of dental health practice. In: Striffler, DF, Young WO, Burt BA. Dentistry, dental practice \& the community. $3^{\text {rd }}$ ed. Sydney: WB Saunders Company; 1983. p. 8-19, 28-29.

8. Freidson E. Profession of medicine: A study of the sociology of applied knowledge. New York: Dodd, Mead Co; 1975. p. 135-8.

9. Broom HN, Longenecker JG. Small business management. Cincinati: South-Western Publishing Co; 1971. p. 20.

10. Domer LR, Synder TL, Heid DW. Dental practice management, concept and application. St Louis: The CV Mosby Company; 1980. p. 3-12, 64-65.

11. Young WO. Career perspectives. In: Striffler DF, Young WO, Burt B. Dentistry, dental practice and the community. $3^{\text {rd }}$ ed. Sydney: WB Saunders Company; 1983. p. 45-52.

12. Woodall IR. Legal, ethical, and management aspects of the dental care system. $2^{\text {nd }}$ ed. St Louis: The CV Mosby Co; 1983. p. 40-42, 48-49, 81-98.

13. Sheiham A. Oral health, general health and quality of life. Bulletin of the WHO, Past issues, 2005; 83(9):641-720.

14. Silker EL. Dentistry, building your million dollar solo practice. Minnesota: Silk Pages Publishing; 1995. p. 13-19, 288-9, 296-8.

15. Kress GC. The impact of professional education on the performance of dentists. In: Cohen LK, Bryant PS. Social sciences and dentistry, a critical bibliography. Volume II. London: Quintessence Publishing Company, Ltd; 1984. pp. 323, 328.

16. Azwar A. Pengantar Admisistrasi Kesehatan. cetakan pertama. Jakarta: Binarupa Aksara; 1996. h. 15-16, 124-5.

17. Anonym. Medical tourism: Globalization. Available at: http:// www.csmngt.co/medical2.htm. Accessed April 23, 2006.

18. Molin DJ, Molin SD. The future of dentistry. Available at: http:// proquest.com/pqdweb. Accessed May 8, 2006.

19. Steele T. The gold watch. Available at: http://www.tysonsteele.com/ n-articles.phtml. Accessed May 8, 2006. 